\title{
How to Train Your Phage: The Recent Efforts in Phage Training
}

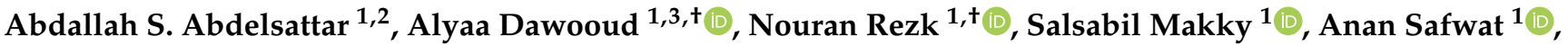 \\ Philip J. Richards ${ }^{4}$ and Ayman El-Shibiny 1,5,*D
}

1 Center for Microbiology and Phage Therapy, Zewail City of Science and Technology, October Gardens, 6th of October City, Giza 12578, Egypt; s-abdallah.abdelsattar@zewailcity.edu.eg (A.S.A.); Alyaa.dawooud@gmail.com (A.D.); p-nrezk@zewailcity.edu.eg (N.R.); syoussef@zewailcity.edu.eg (S.M.); agaber@zewailcity.edu.eg (A.S.)

2 Center for X-ray and Determination of Structure of Matter, Zewail City of Science and Technology, October Gardens, 6th of October, Giza 12578, Egypt

3 Faculty of Pharmacy and Biotechnology, German University in Cairo, New Cairo 11835, Egypt

4 Future Food Beacon of Excellence and the School of Biosciences, University of Nottingham, Loughborough, Leicestershire LE12 5RD, UK; sbzpjr1@exmail.nottingham.ac.uk

5 Faculty of Environmental Agricultural Sciences, Arish University, Arish 4855, Egypt

* Correspondence: aelshibiny@zewailcity.edu.eg; Tel.: +20-100-566-2772

+ Equal contribution.

check for updates

Citation: Abdelsattar, A.S.;

Dawooud, A.; Rezk, N.; Makky, S.; Safwat, A.; Richards, P.J.; El-Shibiny, A. How to Train Your Phage: The Recent Efforts in Phage Training. Biologics 2021, 1, 70-88. https:// doi.org/10.3390/biologics1020005

Academic Editor: Raffaele Capasso

Received: 20 May 2021

Accepted: 29 June 2021

Published: 5 July 2021

Publisher's Note: MDPI stays neutral with regard to jurisdictional claims in published maps and institutional affiliations.

Copyright: (c) 2021 by the authors. Licensee MDPI, Basel, Switzerland. This article is an open access article distributed under the terms and conditions of the Creative Commons Attribution (CC BY) license (https:// creativecommons.org/licenses/by/ $4.0 /)$.

\begin{abstract}
Control of pathogenic bacteria by deliberate application of predatory phages has potential as a powerful therapy against antibiotic-resistant bacteria. The key advantages of phage biocontrol over antibacterial chemotherapy are: (1) an ability to self-propagate inside host bacteria, (2) targeted predation of specific species or strains of bacteria, (3) adaptive molecular machinery to overcome resistance in target bacteria. However, realizing the potential of phage biocontrol is dependent on harnessing or adapting these responses, as many phage species switch between lytic infection cycles (resulting in lysis) and lysogenic infection cycles (resulting in genomic integration) that increase the likelihood of survival of the phage in response to external stress or host depletion. Similarly, host range will need to be optimized to make phage therapy medically viable whilst avoiding the potential for deleteriously disturbing the commensal microbiota. Phage training is a new approach to produce efficient phages by capitalizing on the evolved response of wild-type phages to bacterial resistance. Here we will review recent studies reporting successful trials of training different strains of phages to switch into lytic replication mode, overcome bacterial resistance, and increase their host range. This review will also highlight the current knowledge of phage training and future implications in phage applications and phage therapy and summarize the recent pipeline of the magistral preparation to produce a customized phage for clinical trials and medical applications.
\end{abstract}

Keywords: biocontrol; FDA approval; antibiotics; bacterial resistance; phage evolution; Biofilm clearance; phage arbitrium

\section{Introduction}

The emergence of antibiotic resistance in bacterial pathogens, accompanied by a rise in the attributable mortality [1], has led to considerable research effort being directed toward finding alternative treatments. Bacteriophages (phages) are viruses that infect bacteria [2], and deliberate therapeutic application of phages to infections caused by multi-drug resistant bacteria is a promising alternative to antimicrobials. Phages are the Earth's most abundant biological entity and play a key role in the ecology of microbial communities, including the human microbiota and soil [3,4]. Phages are characterized by a narrow host range and a typical phage particle can only infect a limited number of closely related bacterial species or strains within the same species [5]. When a phage enters the bacterial cell it begins one of two primary life cycles; virulent phages pursue the lytic life cycle where they quickly lyse their host cell and release viral particles, while temperate 
phages can integrate their nucleic acid into the host genome and pursue the lysogenic life cycle [6].

For the treatment of infection, the advantages of phage therapy over anti-bacterial drugs and the challenges facing effective phage therapy are summarized in Table 1.

Table 1. Shows a brief comparison between advantages and disadvantage of phages over antibacterial agents.

\begin{tabular}{cc}
\hline \multicolumn{1}{c}{ Pros of Phages } & Cons of Phages \\
\hline $\begin{array}{c}\text { The efficiency of killing multi-drug resistant bacteria [7,8] } \\
\text { and biofilm clearance [9] }\end{array}$ & $\begin{array}{c}\text { Narrow host range, as sometimes infections involve multiple } \\
\text { bacterial pathogens [5] }\end{array}$ \\
\hline $\begin{array}{c}\text { A narrow host range that causes no considerable harm to } \\
\text { commensal microbiotas [10] }\end{array}$ & $\begin{array}{c}\text { Phage-microbiome interactions in the human body are poorly } \\
\text { understood and phages may have as yet undescribed adverse } \\
\text { effects on microbiomes and host immunity [11-14] }\end{array}$ \\
\hline $\begin{array}{c}\text { Isolation, identification and development of phages from the } \\
\text { environment is an easy and inexpensive processes [15,16] }\end{array}$ & $\begin{array}{c}\text { Some bacteria have evolved resistance against phages through } \\
\text { multiple mechanisms that prevent phage infection [17] }\end{array}$ \\
\hline Low inherent toxicity [18] and auto-dosing [19] & Immunogenicity [20] \\
\hline
\end{tabular}

The advantages of phage therapy and the challenges facing effective phage therapy have been comprehensively reviewed elsewhere by Loc-Carrillo and Abedon [21].

The key advantage of phage therapy over antibiotics is that phages respond to bacterial defenses; for example, phage host range has been expanded through both evolutionary selection and genetic engineering [22,23]. Furthermore, phages have the ability to overcome bacterial resistance mechanisms and increase their host range through adaptation or training [23-26].

Co-evolution studies employ the Appelmans protocol to understand the phage adaptation to bacterial hosts, which is known as "phage training" [25]. Phage training can be divided into natural, enforced, and engineered. In natural phage training there is no bias between the selection of bacteria and phage; both are developed on the same track to keep the balance that exists in nature without human interference. However, in enforced phage training, selection is biased toward the phage, for example by countering phageresistant secondary bacterial growth through co-treatment with silver nanoparticles [27] or antibiotics [28]. It is important to distinguish between pseudo-enforced phage training approaches where the effect is temporary and dependent upon the effector, for example using antibiotics to convert lysogenic cycle to lytic in temperate phage [29], and enforced phage training where the induced changes are permanent, for example exposing the phage to a chelating agent $[30,31]$. In engineered phage training selection is absolutely biased toward the phage as it evolves naturally after engineering.

Although phages are a highly promising alternative to antimicrobial agents, there are presently a number of recognized drawbacks due to bacterial defense mechanisms and limits in our scientific knowledge, as outlined above. Stemming from this, we need to better understand and predict phage behavior in order to develop safe and efficacious applications. This review aims to highlight the common strategies based on previously approved regulations [32,33] to optimize phage agents for biocontrol applications, including how phages can be deliberately switched between lytic and lysogenic cycles and how a better understanding of phage:bacteria interactions will subdue the development of bacterial resistance and expand phage host range. The review will also describe the various regulations and approvals in place for using phages in biocontrol of pathogens. By pinpointing the maneuvers that phage naturally execute, we can manipulate phage behavior to benefit therapeutic applications.

\section{Training Phage Lysogenic-Lytic Decision}

\subsection{Training Phage to Be Lytic}

The process of controlling the phage to switch from lysogenic cycle to lytic cycle opens the door for researchers to control the replication dynamics of prophages and train them 
to get maximum benefit from using them to control pathogenic bacteria. Lytic phages are of special interest given their role as a bacterial control agent and have advantages over the lysogenic phage which were described elsewhere [34]. Many experiments have been designed to achieve the lytic-lysogenic switch in the laboratory. In one experiment, the universal lysis-inducing agent, Mitomycin-C, was employed to induce the phages of Serpulina hyodysenteriae, in which bacteria were incubated for around $7 \mathrm{~h}$, then studied [35]. The treated culture showed lower optical density, and phage particles were detected using an electron microscope and an extrachromosomal band, indicative of phage nucleic acid, was visualized by gel electrophoresis [35]. Other studies have used forward genetics to explore the bases of lysis activity in phage. For example, one study incubated the SA13 temperate phage in sodium pyrophosphate to induce mutation before viable, lytic phage were recovered by picking phages that produce clear plaques on lawns of susceptible Staphylococcus aureus bacteria [36]. This process was repeated 25 times at which point the phage showing the best lysis effect was isolated and named SA13m. Compared to the SA13 wild-type phage, the virulent mutant SA13m did not show lysogens and could lyse bacterial cells faster than the wild-type [36]. Moreover, the comparative genome analysis done for both SA13 and SA13m showed random mutations that resulted in non-functional truncated genes in SA13m that included integrase, CI repressor, anti-repressor protein, and other proteins belonged to the lysogen decision gene cluster [36]. The pyrophosphate method to generate strictly non-temperate phages was previously applied by other researchers [31]. Although both papers promote genome deletions, the resulting genomes had the same length and both did not demonstrate with sufficient controls that the supposedly obligate non-temperate phages really could not undergo the lysogenic life cycle.

Studies have shown that prophage can shift to the lytic cycle under stress conditions such as $\mathrm{pH}$. In a study by Choi et al. [37], various inducing factors were examined against Nitrosospira multiformis, an ammonia-oxidizing bacteria used in wastewater treatment. Culturing in sub-optimal acidic culture media $(\mathrm{pH} 5)$ was observed to increase the number of non-viable bacterial cells and the number of virus like particles (VLPs) relative to a control cultured under optimal $\mathrm{pH}$ conditions ( $\mathrm{pH} 7$ ), which indicates that the phage shifted into a lytic mode of action. In addition, a series of experiments showed an increase in VLPs in response to an increase in chlorine (IV) concentration from 0.002 to $0.1 \mathrm{mM}$; above $0.1 \mathrm{mM}$ chlorine (IV) the number of VLPs and bacterial count are decreased due to chlorine (IV) toxicity. At low $\left(<4{ }^{\circ} \mathrm{C}\right)$ and high $\left(>45^{\circ} \mathrm{C}\right)$ temperatures, the growth of $N$. multiformis is inhibited, but at $35{ }^{\circ} \mathrm{C}$ VLPs are increased and the cell viability is decreased, indicating the lytic switch [37]. These results highlight the possibility of using prophage under acidic conditions and even in the presence of low level of chlorine to control pathogenic bacteria.

\subsection{Training Phage to Be Lysogenic}

The lytic to lysogenic switch is less studied, which might be due to several reasons: (i) virulent phages have clearer application as antimicrobial and biocontrol agents thereby researchers tend to be less interested in lysogenic phages [36], (ii) temperate phages exert less selective pressure on bacterial ecosystems relative to virulent phages as lytic phages kill $\sim 20 \%$ of the bacterial community per day [38], (iii) fewer methodologies are optimized to study lysogeny, e.g., no direct tests to count the lysogens have been reported and studies rely on triggering the lytic switch to quantify phage by counting the resulting phage particles with a large margin of error and possibility of false negative results [37]. Other studies rely on metagenome sequencing, which at this time is both relatively expensive and requires a high-performance computer infrastructure [39]. Older lysogenisation tests are outside of the scope of this review and have previously been well critiqued by Kourilsky [40].

Whilst the lysogenic decision takes place when a phage switches its replication mode from the lytic to the lysogenic cycle, phages can also inhibit lysis without the need of a replication mode switch. Phage superinfection exclusion (Sie), happens when phages are 
not allowed to enter the host cell due to the presence of the same or closely related phages within the bacteria [41]. During Sie phages undergo lysis inhibition waiting for all the in-host phages to lyse the host bacteria and be released into the external environment [42]. This is distinct from a lysogeny switch as during Sie phages halt the lysis, but do not undergo lysogeny. Multiplicity of infection (MOI) is one of the factors that encourage lytic to lysogenic switch [40] and there is a direct relationship between the phage ratio to bacterial number and switching processes in the temperate phage; Kourilsky (1973) suggested that the high average number of phages in bacterial host cells (or high MOI) favors the lysogenic mode of action [40]. Moreover, infection by more than one replicating phage leads to lysogenisation, while infection with a single phage is likely to result in lytic replication. However, recent work suggests that it is not applicable for a bacterium to be infected by more than one phage or phagemid due to Sie and P3 expression [41,43]. These results are explained by Abedon's rationale, when he suggests that as the virulent phages disrupt more and more bacterial hosts the number of susceptible host cells decreases [44], which places a burden on the phages, as if they do not find sufficient host cells to infect they face deactivation. One way to avoid that burden, is for phages to inhibit the lysis process or go into lysogenic switch and pass their genome along with the bacteria to balance the cell density and the phage to host cell ratio, and that is why as the MOI increases, the isolated phages will be mostly temperate phages.

$\mathrm{CII}$ is a working gene in the lysogenic decision gene cluster and it has been shown that increasing the initial phage titer elevates expression of transcription factors and consequently increases CII gene expression [45-47]. Another study found that CII gene increases as the integrated phage particles increases [48]. Further investigations showed that CII gene upregulates the CI gene, which is the main agent in the phage lysogenisation process [45-47]. Respectively, the trainer can control the phage attitude between lytic and lysogenic cycles by adjusting the initial inoculum, since a larger inoculum of bacteria or lower inoculum of phage switches on the lytic cycle.

A study of a coral reef ecosystem associated increased bacterial density with a lytic to temperate phage switch [49]. Genes encoding integrase, excisionase proteins, and prophage hallmarks were all detected by metagenomic analysis of phages isolated from environments with fast growing bacteria. These findings suggest that in cases of fast-growing bacteria, phages chose the lysogenic cycle and piggyback the bacteria. The Piggyback-the-Winner $(\mathrm{PtW})$ model, describes the positive relationship between bacterial densities and the lytic to lysogenic switch and opposes the long favored hypothesis, Kill-the-Winner (KtW) model, which suggests that lytic phages predominate when the number of bacteria cells is increasing [50].

\subsection{Phage Communication Shapes Lytic-Lysogenic Decision}

The importance of communication between bacteria (quorum sensing) has been recognized since the late 1960s [51,52], but recent discoveries have shown that phages are also "socially" communicating important information to boost their surveillance just like bacteria [53]. One footprint of phage communication is lysis inhibition. In cases of superinfection exclusion, detailed in Section 2.2, lysis inhibition suggests a kind of communication among phages as phages somehow sense the hardship in tethering (adsorbing) and entering the bacterial host, then choose communally to undergo lysis inhibition until all primary infection phages lyse the bacterial host. After the first round of infection and lysis is completed, the phages switch back to lysis mode and infect bacterial host [42]. Furthermore, Abedon [44] highlighted a dilemma in this scenario when he asked how some phages (outside the host cells) could inhibit the lysis process, while other phages (inside the host cells) continue their normal lysis replication cycle.

The details of how phage particles can sense host cell stress were unclear until the purification of a small signal peptide that facilitates the phage communication [54]. The experiment detected a hexapeptide moiety that is secreted during the lytic cycle, but encourages the phage to commit to the lysogenic mode as it accumulates. Release of 
the peptide communicates that phages have successfully lysed the bacterial host and increased [55] concentrations indicate more and more successful phages, and corresponding lower host abundance (high MOI), which encourages phages to switch to the lysogenic cycle [56]. In the absence of this signaling moiety, however, the phages are induced to switch into the lytic mode. This finding is revolutionary in the field of sociovirology as it opens a new horizon for the peptide-based decisions for viruses $[57,58]$.

\section{Training Phages against Phage-Resistant Bacteria}

Phages and their bacterial hosts compete to survive. Meanwhile, they boost the diversity of several microbial ecosystems [59]. In vitro experiments suggest that bacteria-phage co-evolution contributes to the potential of employing phages in therapeutic approaches. Unlike antibiotics, phages maneuver to overcome the antiviral mechanisms raised by the bacterial hosts [60]. In this section, we will discuss the mechanisms of bacterial resistance and how phages overcome these challenges (Figure 1).

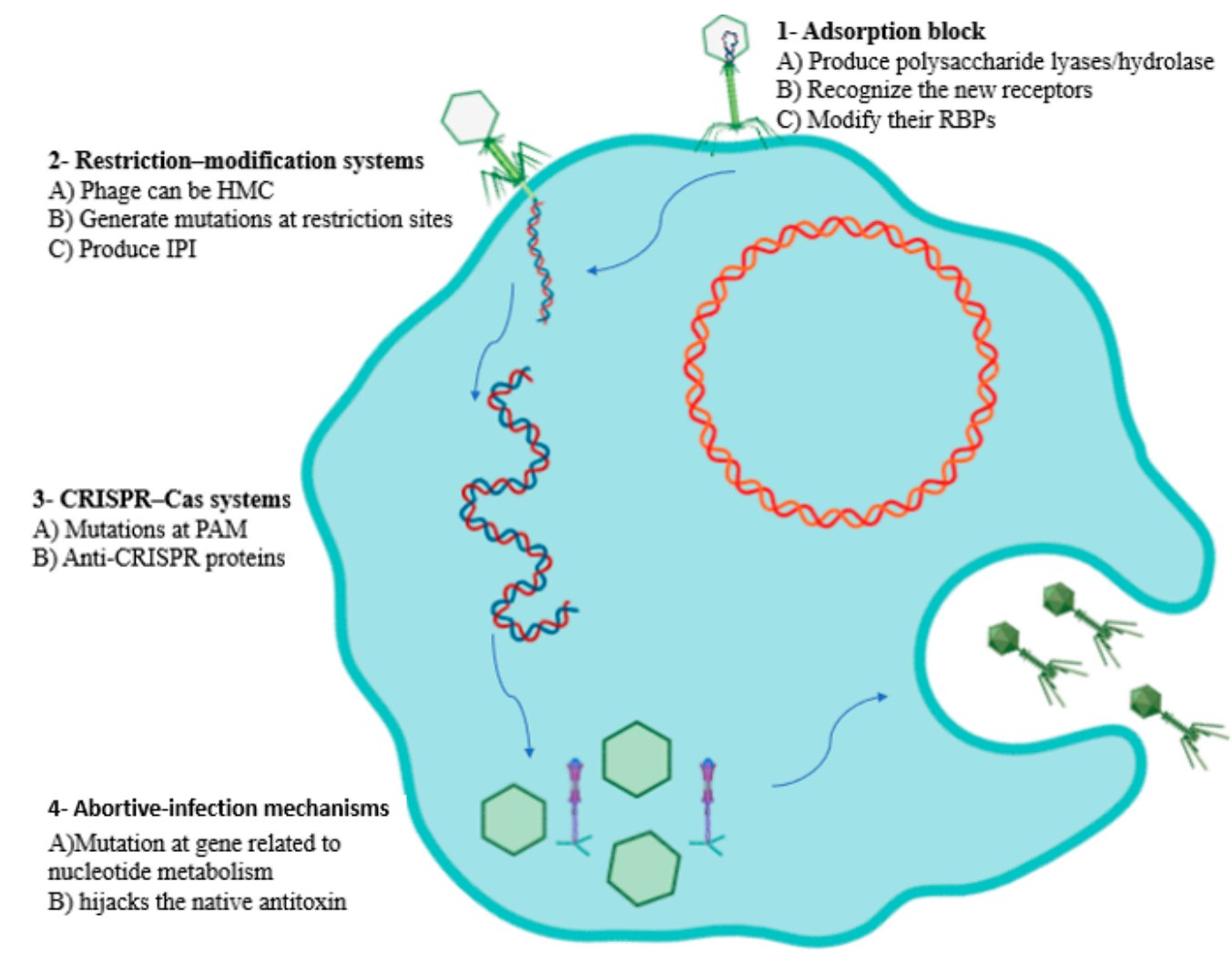

Figure 1. Phage interruption mechanisms against bacterial resistance. The figure shows the four steps of the phage life cycle where it responds to bacterial host cell defense.

\subsection{The Mechanisms That Bacteria Use to Resist the Phage}

To successfully infect a bacterium, phages must first adhere to receptors presented on the cell surface and then inject their nucleic acids into the host to commence replication. Bacteria have developed numerous defense mechanisms against each of these steps and here we will review the four main approaches: (i) preventing phage adsorption, (ii) preventing phage nucleic acid entry, (iii) cutting phage nucleic acids, (iv) activating abortive infection systems. Other defense mechanisms are described elsewhere [17]. The process of bacterial resistance toward phages is of critical importance to the health and drug discovery sector in the future. Anti-bacterial-resistance mechanisms are summarized in Figure 1 and will be detailed in the following sections. 


\subsubsection{Preventing Phage Adsorption and Nucleic Acid Entry}

Tethering of phages to bacterial receptors and nucleic acid entry are fundamental steps of the infection process and a variety of obstacles have evolved in bacteria to block them. For instance, to resist phage adsorption, bacteria developed several techniques to prevent phage from binding host receptors. For example, S. aureus produce protein A [61] and Escherichia coli produce TraT protein [62], which mask the phage receptor and modify cell surface receptors, respectively. Other bacteria such as the Pseudomonas produce alginates, which are polysaccharide moieties secreted into the extracellular matrix that prevent the phage entry into the cell [63-65] and some bacteria use molecules that work as competitive inhibitors for the phage receptors [66]. Moreover, temperate phages can produce membrane-associated proteins to activate the previously illustrated phenomenon: Sie, which inhibit other lytic phage from injecting DNA into the bacterial host when the primary phage is still inside [67].

\subsubsection{Cutting Phage Nucleic Acids}

Bacteria destroy the invading phage nucleic acids through one of three defense systems: (i) restriction-modification, (ii) prokaryotic argonautes (pAgos), and (iii) Clustered Regularly Interspaced Short Palindromic Repeats with CRISPR associated genes (CRISPRCas) system. The restriction-modification system uses restriction enzymes to cut the injected phage genome at specific restriction sites [68]. Bacteria have evolved modification dependent systems (MDSs) to differentiate between methylated and hydroxymethylated DNA [69]; for example, E. coli CT596 has glucose-modified restriction systems: S and D that cleave glucosylated hydroxymethylcytosine (HMC)-containing DNA, which have no effect on unglucosylated DNA [70]. Moreover, E. coli bacteria produce fused polypeptide GmrS and GmrD that can prevent the effect of internal protein I (IPI) in phage and block phage infection $[70,71]$.

The CRISPR-Cas system is a complex adaptive system against phage invasion [72]. This system includes the spacers, which have around 30-40 nucleotides from the invading phages, that are first transcribed into small CRISPR RNA (crRNA) guides. CRISPR types I, II, and $\mathrm{V}$ use crRNA guides to detect the complementary sequence in the invading phage genome called a "protospacer" and they need a conserved protospacer-adjacent motif (PAM) located beside target DNA [73-75], whereas both Types III and VI do not need PAM [76,77], and Type VI CRISPR targets RNA only [78]. On the other hand, pAgos are newly recognized as bacterial innate defense mechanisms [79]. Agos relies on degrading the invader DNA sequence non-specifically, then using this as guide DNA that provides sequence-specific interference facing the same target $[80,81]$. To date, various mechanisms have been illustrated, such as DNA-guided DNA silencing [82] and RNA-guided DNA silencing [81]. The phage can be trained by developing anti-CRISPR-Cas system genes [83] which can be done through artificial selection.

\subsubsection{Activating Abortive Infection Systems}

Abortive infection (Abi) system appears in a bacterial community as a form of altruism as a bacterium will sacrifice itself to protect the surrounding community through programmed cell death. In Abi, bacteria prohibit the release of functional phage particles along with toxin-antitoxin (TA) systems [84]. TA systems have toxins, proteins which reduce the metabolism level without killing the bacteria. The phage progeny is reduced due to the lower metabolic activity of the host [85].

\subsection{The Phage Interrupting Bacterial Defenses}

Phages overcome various resistance mechanisms raised by bacteria. Thus, the coevolution process is dynamic as we can still see both of them in nature. Phages are able to recognize and deal with changed bacterial receptors and successfully adhere to the bacterial cell. Phages can also bypass the modification dependent systems (MDSs) that 
are produced by the bacteria and employ their own anti-CRISPR system against bacterial adaptive immunity.

\subsubsection{Phages Defeat MDS Systems and Receptor Change}

A number of different strategies for overcoming host MDS systems have evolved in phages. Some phages have glucosylated hydroxymethylcytosine (HMC) or a methylated genome to avoid particular endonucleases [86] and phages can also accumulate mutation to lose the restriction sites such as Staphylococcus Phage K, which loses the Sau3A restriction site in both DNA double-strands [87,88]. Furthermore, phage T4 may earn a resistance to MDSs by the glucosylation of HMC residues [60]. Some T4-like phages can produce 76-amino-acid-residue nuclease inhibitor, IPI, into the bacterial host, to inhibit the unfused GmrS-GmrD system. So, those phages are allowed to infect E. coli strains that have this system [71]. To overcome receptor changes phages can produce polysaccharides such as lyases or hydrolases to "shew" the adsorption obstructs [89,90].

\subsubsection{Anti-CRISPR and Anti-Abortive Infection (Abi) Systems}

Phages develop mechanisms to avoid bacterial CRISPR-Cas and Abi systems. For instance, anti-CRISPR proteins (Acr), whose transcription is regulated by anti-CRISPRassociated (Aca) proteins, were found to be able to increase the fitness of phages against almost all CRISPR-Cas systems [91,92]. Phages could also avoid CRISPR-Cas systems by producing mutations at PAM sites [93]. Furthermore, phages have anti-abortive infection machinery, such as mutations in the nucleotide metabolism genes of Lactococcus spp. phages that allow them to escape from AbiQ mechanism [94] and phage TE produces pseudoantitoxin RNA which contributes in preventing toxin-antitoxin systems in bacteria [95].

\subsection{Training Phage to Overcome Resistant Bacteria}

As phages adapt to bacterial resistance naturally, we can artificially train them against resistant bacteria. Phage-resistant bacteria are the major drawback of phage applications and much attention is devoted to recognizing examples of host resistance in natural ecosystems [25]. E. coli O157:H7 is a pathogenic bacterium with the ability to form mutant strains that resist PP01 phage. A study found that following $100 \mathrm{~h}$ of incubating the resistant bacteria with PP01 phage, that the phage became naturally trained to lyse the bacteria [96]. Another study focused on Pseudomonas aeruginosa PAOw-1, a Pseudomonas strain with an altered O-antigen on its receptors that confers resistance to PaoP5 phage infection. A trial employed phage training to produce a phage capable of overcoming this obstacle and following several transfer experiments the resultant "trained" phage exhibited alteration in genes that encode phage receptor binding proteins. The mutation yielded a synthetic phage called PaoP5-m1, with a mutation A715C in orf75 that enabled the phage to recognize the mutated receptor of PAOw-1. In this case phage training worked against an altered and truncated O-antigen, but training failed against the total loss of the O-antigen [97].

However, bacteria are also able to evolve as a response of phage attack. For instance, after a susceptible P. aeruginosa PAO1 was serially challenged six times with panel of phages a mutant bacteria strain was selected that resists ancestors of two phages of the panel. However, correspondingly, after six serial transfers the trained phages had the ability to lyse both P. aeruginosa PAO1 and the mutant strain [98,99]. This finding suggests the co-evolution between the bacteria and phage might increase the potential of phage usage in therapeutics.

Nonetheless, the co-evolution of bacteria has a burden on its growth. Pseudomonas fluorescens with its phage phi2 is a model for long co-evolutionary dynamics between bacteria and phage. The findings showed that bacteria with phage generate more mutations than those incubated without phage [100]. Moreover, the phage-resistant bacteria had a slower growth rate and were less virulent; representing a fitness cost [101]. 


\section{Host Range}

The range of bacterial strains that are recognized and infected by phage is known as the "phage host range". Phages are classified based on their host range as monovalent or polyvalent phages [102]. Monovalent phages infect limited strains of bacteria by binding to a single receptor with a narrow host range; whereas polyvalent phages bind to many different receptors and have a broad host range. The most common phages are monovalent and are restricted to a small number of bacterial strains of the same species. The narrow host range can be advantageous in phage applications as the applied phage cannot affect potentially beneficial off-target bacteria. Due to the massive variety in bacterial strains, it is hard to identify all the infecting bacterial strains and all their specific phages. In addition, some infections are caused by multiple bacterial strains, so it is even harder to isolate a single phage active against them all $[2,103]$. Therefore, deliberately expanding the phagehost range by phage training can solve these challenges in several phage applications.

\subsection{Factors Determine Phage Host Range}

Phage receptor binding proteins (RBPs) are the primary determinant of host range. Phages initiate infection by binding to bacterial host receptors including saccharides, proteins, and organelles using their RBPs (Figures 2 and 3). RBPs are located at the tip of the tail and vary in structure between phages according to their morphology. The majority of changes in the attachment mechanism between the phage and its host are due to alterations in the RBPs [104]. Accordingly, RBPs became the main target of several studies to expand the phage host range and potentially widen the range of phage applications, however biochemical interactions during infection and the phage-resistance mechanisms employed by the host (see Section 2) also contribute to shaping phage host range [5].

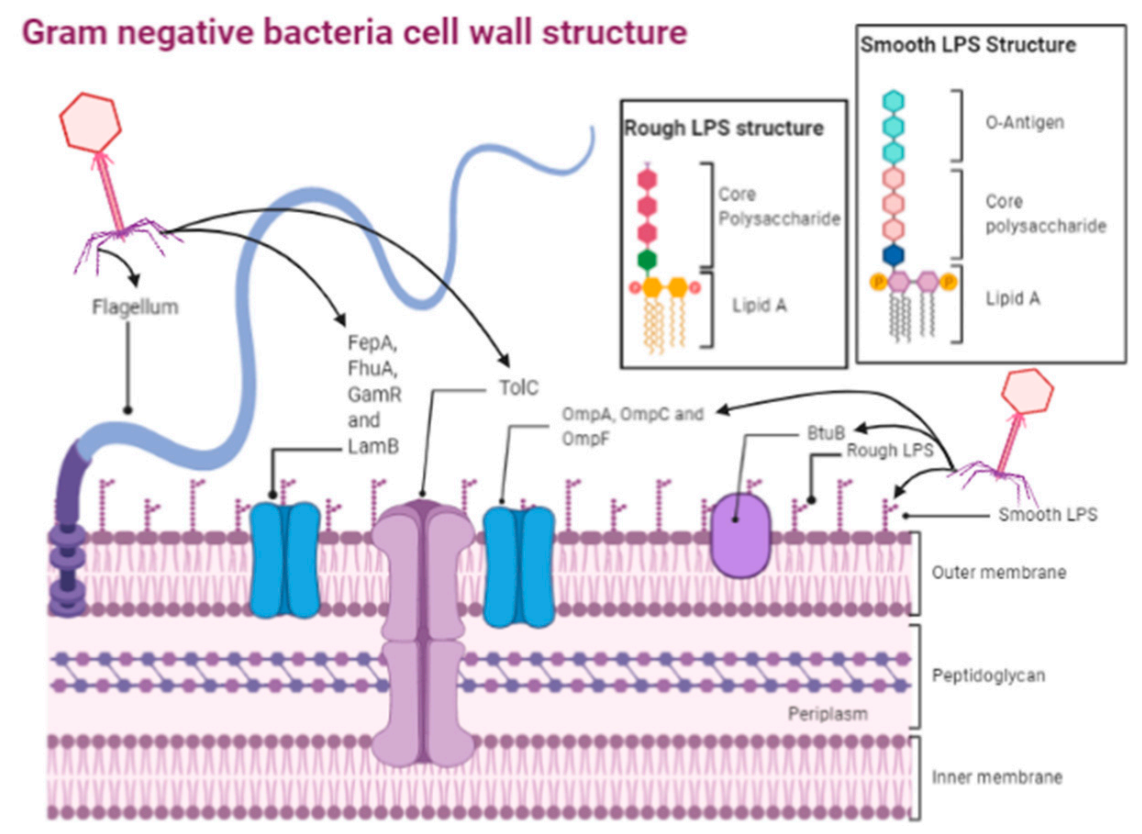

Figure 2. Target receptors of Gram-negative bacteria for phage adsorption including lipopolysaccharides, and flagellum. 


\section{Gram positive bacteria cell wall structure}

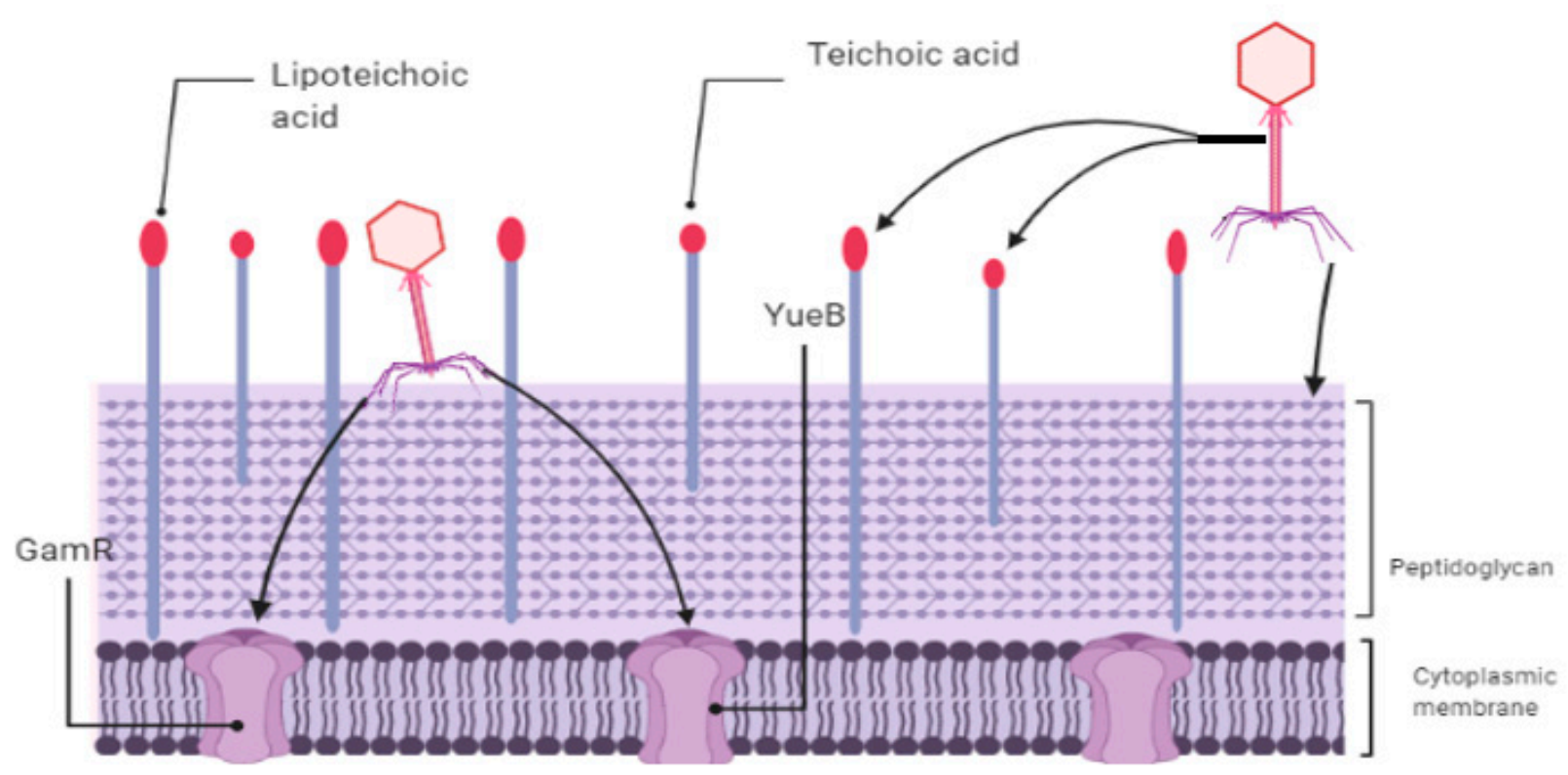

Figure 3. Target receptors of Gram-Positive bacteria for phage adsorption including peptidoglycan, lipoteichoic acid, teichoic acid, and integral proteins in cytoplasmic membrane.

\subsection{Methods of Host Range Expansion (HRE)}

\subsubsection{Natural Co-Evolution}

Phage-host coevolution is a natural process that sustains both phage and bacterial existence. The bacteria dynamically form anti-phage barriers and employ adsorption blockers to prevent phage tethering and phages evolve accordingly to overcome these barriers along with expanding their host range, ensuring the survival of both phages and bacteria.

It has been shown that $E$. coli and its phage T7 coevolve for the benefit of the phage. When T7 phage expanded its host range to include a mutated E. coli, these trained phages were less sensitive resistance in the initial bacterial population [105]. In addition, studies have shown that the continuous mutations occurring in co-cultured bacteria and phages increase the phage host range. A study that performed four co-evolution experiments, where EfV12-phi1 phage was grown on Enterococcus faecium with serial transfers twice daily for eight days [106]. Genome sequencing highlighted that $E$. faecium resists phage due to mutations in the $y q w D 2$ gene, which is involved in exopolysaccharide biogenesis and export. In addition, more mutations were placed in the rpoC gene, which is responsible for the synthesis of the RNA polymerase $\beta^{\prime}$ subunit. EfV12-phi1 phages adapt to these mutations by evolving tandem duplications within a putative tail fiber gene, which increased phage adsorption to several strains of E. faecalis. Host range assays concluded that co-evolution causes blockage of bacterial adsorption at first, whereas phage infectivity increases over time due to mutations in its tail fiber [106].

Appelmans Protocol

The Appelmans protocol is currently used to expand phage host range. It relies on serial passages of co-infection using a continuous culture of a trained phage with the same original wild-type host at each passage [23]. The protocol showed promising results 
to expand the host range of $P$. aeruginosa-specific phages. Researchers used cocktails of phages to expand phage host range, prevent formation of the biofilm, and to reduce the pre-existing biofilm of $P$. aeruginosa strains. The Appelmans protocol was then modified by using seven clinical and three laboratory strains of P. aeruginosa (two of them were sensitive to phages) and a cocktail of three Pseudomonas phages. The phage cocktail was incubated with each bacterial strain and after 30 rounds of applying the protocol, the host range of isolated phages' progenies was expanded since the seven clinical Pseudomonas strains became sensitive to all phages. The genetic analysis revealed that many recombination events occur between the two most closely related phages in the cocktail. These results suggest that the Appelmans protocol can expand the host range of phage cocktail without new genetic information being added [23].

Natural Co-Evolution: Role of Acquisition of Sensitivity in Host Range Expansion

In the acquisition of sensitivity (ASEN) phenomenon, the receptors of the sensitive bacterial hosts exchange with the adjacent resistant cells. Researchers using resistant and sensitive strains of Bacillus subtilis and lytic phage SPP1 found that resistant cells, which lack the SPP1 receptor, are killed when co-cultured with sensitive cells. This exchange is an example of horizontal gene transfer that occurs between different strains to allow phage adsorption to non-host strains [107]. Many factors boost the process of expanding phage host range along with the Appelmans protocol: (i) using a virulent phage cocktail is essential to allow recombination with diversity; (ii) using both clinically relevant and up-to-date bacterial isolates that are resistant to the cocktail; (iii) including a sensitive bacterial host for lytic growth of most or all the phages in the cocktail [23].

\subsubsection{Genetic Engineering of Phage-Host Range}

Genetically engineered phages offer another approach to expand host range for multispecies bacterial communities. It is achieved by displaying hybrid phage tail or tail fiber proteins to expand host range. Phage engineering has been applied to several species of Klebsiella, Salmonella, Escherichia, Shigella, and Enterobacter [108]. Furthermore, synthetic biology has been used to alter E. coli phage scaffolds to target pathogenic Yersinia and Klebsiella bacteria and alter Klebsiella phage scaffolds to target $E$. coli by modular swapping of tail components of the phage [109].

As a key factor in host range research, effort has focused on the phage RBPs as the C-terminal region in particular is one of the most important determinants for host range specificity. On the other hand, other regions may indirectly alter receptor specificity by changing binding site supportive capacity. A study used T4-like phage, WG01, to change the host range of another T4-like phage, QL01, by replacing different parts of the hostdeterminant gene in its tail fiber protein with that of QL01 [22]. The results showed that a mutation of a single nucleotide in phage RBPs can change the host specificity. They also highlighted recombination events in the RBP domains in the new phage, WQD, which led to host range expansion to involve the parent phages and the novel hosts [22].

\subsection{The Applications for Phage Training}

The first study that used the concept of phage training was conducted and published in 2013 [98], but the concept has yet to be fully exploited. The main aim for this is to reduce the risk of bacterial resistance toward phages by producing more evolved phages that can be used in disinfecting surfaces at hospitals [98]. Recently, it was reported that phage can be evolutionary accelerated over 28 days through phage training that enabled phage to suppress bacteria by about 1000-fold more than the untrained ancestor phage [110]. However, the balance between cost and benefit should be investigated more.

\section{Legal Regulation of Phage Therapy}

The optimal application for trained phage falls within human therapy. Pharmaceutical legislation and regulation were designed to serve pharmaceutical industries and large-scale 
production, not customized products, and there is no compatible regulatory framework for phage therapy in many countries. However, many successful models have been developed to employ phages in therapeutic applications for human disease, where emergency approval was given for individual cases with the general five prerequisites: Availability, Production, Formulation and Administration, Dosage, and Therapeutic Evaluation [111].

\section{Approval of Clinical Trials}

Several clinical trials have been conducted in humans that use phage as an alternative therapy, all of which were based on isolated phages often in the form of a cocktail. In 2009, phase I/II of a clinical trial were approved by the Central Office for Research Ethics Committees (COREC) and Medicines and Healthcare Products Regulatory Agency (MHRA) in the United Kingdom. In this trial, phage therapy against antibiotic-resistant P. aeruginosa (Biophage-PA) was tested on 24 patients [111]. In 2009, Phages for Human Applications Group Europe in Belgium was founded as a non-profit organization to fill the gap in phage therapy [112]. In 2010, Eliava Phage Therapy Center in Georgia was established to supply patients with phage-based treatment in their home [113]. In the USA. the FDA has approved a clinical trial phase I to use a phage cocktail prepared by Intralytix as a therapy for leg ulcers [114]. Since 2011, the Western Sydney human research ethics committee of Australia approved phage therapy for compassionate use to treat P. aeruginosa urinary tract infections [115]. Moreover, in 2015 Poland, a European Union member, established a phage treatment facility with support from Hirszfeld Institute. This gave them authorization for the first ethically approved phage therapy in Europe, with over than 700 patients enrolled in phage therapy under the approval of Independent Bioethics Committee (opinion No. KB-349/2005) [116]. In addition, the phage therapy in Poland was conducted under "experimental treatment" regulations [117]. In France, phage therapy was used under nominative temporary authorization [118] and in 2017, under the umbrella of the Declaration of Helsinki, a patient received intravenous phage as a monotherapy to fight P. aeruginosa [119]. Moreover, from April 2013 to April 2018, there were 15 patients receiving phage therapy against different bacterial strains in the Queen Astrid military hospital (QAMH) in Brussels, Belgium [119,120]. In 2017, the Food and Drug Administration (FDA) approved to use the phages under Emergency Investigational New Drug (EIND), in which patients were treated by intravenous phages against resistant Acinetobacter baumannii [121]. In 2019, the FDA approved the first clinical trial in USA for intravenous phage therapy [33] and collaboration between France and Belgium to use a cocktail of phages against P. aeruginosa in a study that was known as "PhagoBurn" [122]. Currently, there are nine clinical trials recruiting for phages for different diseases Table 2. The potential problem that will be encounters is that when a trained phage is used it will be considered a novel phage, different from the wild-type and requiring full evaluation from the beginning.

Table 2. Current clinical trials for phage to be used as a therapy or sensor for human diseases. Data obtained from www.clinicaltrials.gov (accessed on 9 March 2021).

\begin{tabular}{|c|c|c|c|}
\hline NCT Number & Conditions & Title & Sponsor/Collaborators \\
\hline NCT04650607 & Prosthetic joint infection & Phage safety cohort study & Hospices civils de Lyon \\
\hline NCT04287478 [123] & $\begin{array}{l}\text { Urinary tract } \\
\text { infection bacterial }\end{array}$ & $\begin{array}{l}\text { Phage therapy in patients with } \\
\text { urinary tract infections }\end{array}$ & $\begin{array}{l}\text { Adaptive phage therapeutics, Inc., } \\
\text { and United States department } \\
\text { of defense }\end{array}$ \\
\hline NCT04724603 & Bone and Joint Infection & $\begin{array}{c}\text { Phage Safety Retrospective } \\
\text { Cohort Study }\end{array}$ & Hospices Civils de Lyon \\
\hline NCT04596319 [124] & Cystic fibrosis & $\begin{array}{l}\text { Ph } 1 / 2 \text { Study Evaluating Safety } \\
\text { and Tolerability of Inhaled } \\
\text { AP-PA02 in Subjects with Chronic } \\
\text { Pseudomonas Aeruginosa Lung } \\
\text { Infections and Cystic Fibrosis }\end{array}$ & $\begin{array}{l}\text { Armata pharmaceuticals, Inc., } \\
\text { and cystic fibrosis foundation }\end{array}$ \\
\hline
\end{tabular}


Table 2. Cont.

\begin{tabular}{|c|c|c|c|}
\hline NCT Number & Conditions & Title & Sponsor/Collaborators \\
\hline NCT03808103 [125] & Crohn Disease & $\begin{array}{c}\text { Safety and Efficacy of EcoActive } \\
\text { on Intestinal Adherent Invasive E. } \\
\text { Coli in Patients with Inactive } \\
\text { Crohn's Disease }\end{array}$ & $\begin{array}{l}\text { Intralytix, Inc. and Mount } \\
\text { Sinai hospital }\end{array}$ \\
\hline NCT02957370 [126] & Urinary Bladder Neoplasms & $\begin{array}{l}\text { Molecular Biosensors for } \\
\text { Detection of Bladder Cancer }\end{array}$ & University of California, Irvine \\
\hline NCT03326947 [127] & Neoplasm Neck & $\begin{array}{l}\text { Phage II Trial of Stathmin as } \\
\text { Predictive Biomarker for TPF } \\
\text { Induction Chemotherapy } \\
\text { in OSCC }\end{array}$ & $\begin{array}{l}\text { Shanghai Jiao Tong university } \\
\text { school of medicine }\end{array}$ \\
\hline NCT03967236 & Inflammatory bowel diseases & $\begin{array}{c}\text { Impact of Intestinal Virome on } \\
\text { Pediatric Inflammatory } \\
\text { Bowel Disease }\end{array}$ & Hospices civils de Lyon \\
\hline NCT03418454 [128] & Oral squamous cell carcinoma & $\begin{array}{c}\text { The Oral Microbiome as a } \\
\text { Prognostic Tool in Oral Malignant } \\
\text { and Premalignant Lesions and in } \\
\text { Medication Related Osteonecrosis } \\
\text { of the Jaw }\end{array}$ & Barzilai medical center \\
\hline
\end{tabular}

The idea of magisterial phage preparations originated from the magisterial preparations concept which is identified as "any medicinal product prepared in a pharmacy in accordance with a medical prescription for an individual patient" (Article 3 of European Directive 2001/83 and Article 6 quater, 3 of the Law of 25 March 1964). A clear phage therapy framework was proposed to be followed (Figure 4). This approach is used in Germany, Netherlands, Belgium, and France [117]. Unlike chemical compounds and enzymes, phage undergo mutations throughout its genome whenever the replication process occurs [129]. Based on that, we highly recommend re-evaluation of the current regulations for using the phage as a therapy, especially regarding phage training.

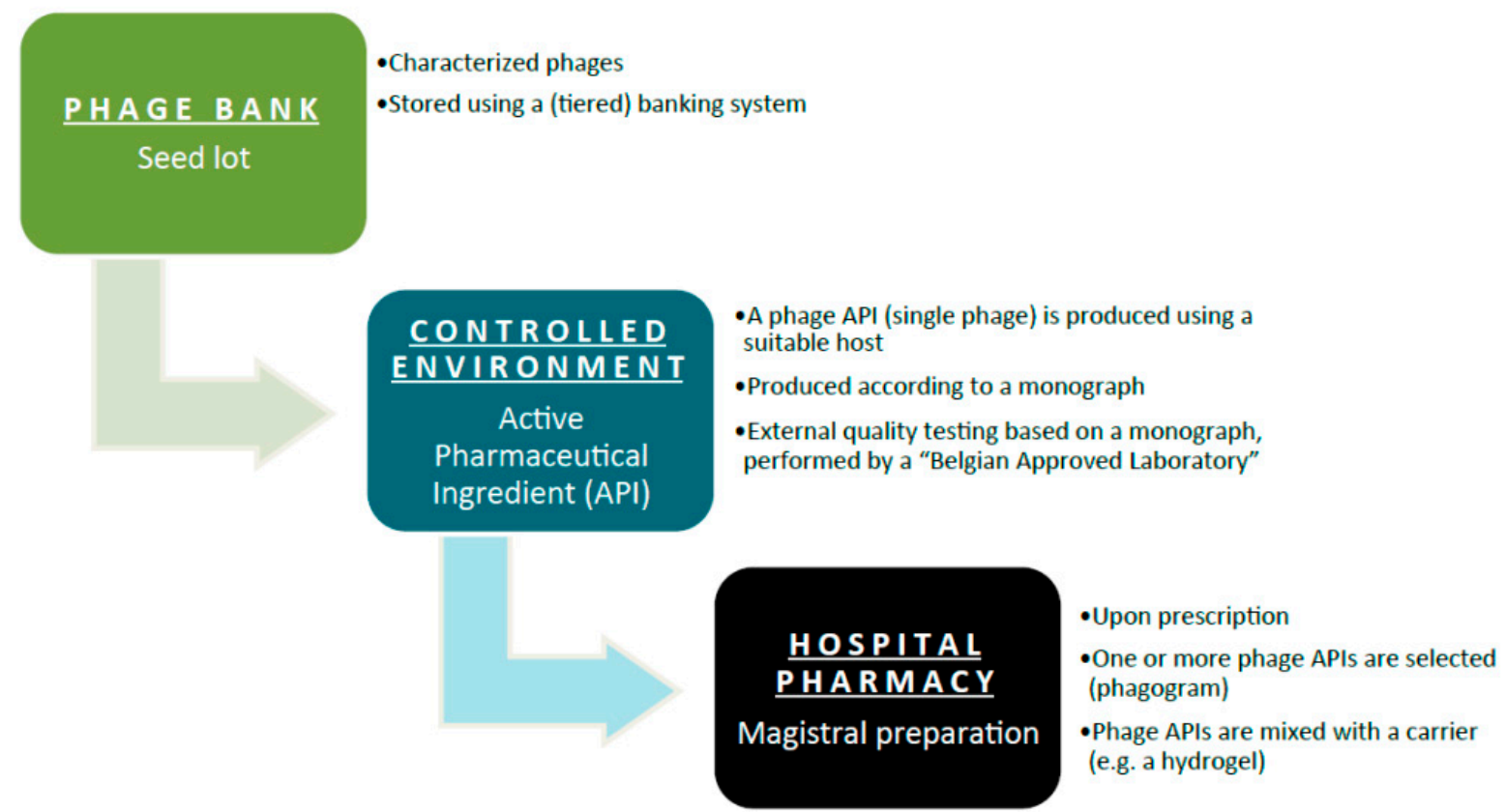

Figure 4. Shows the flow of magistral phage preparation retrieved from Pirnay et al. [130]. 
However, the situation in plant crops, animal products, food, and living animals is better since there are various commercial phage-containing products from different manufacturers. In the USA, OmniLytics Inc. specializes in producing phages for agriculture, while Intralytix Inc. produces phage-containing products for poultry, pet food, and human food and Elanco Food Solutions has phage products for hide-washing [131]. Micreos Food Safety in the Netherlands decontaminates meat surfaces and MRSA on human skin using phages and endolysins, respectively. APS Biocontrol Ltd. in the UK is specialized in the treatment of potatoes with phages and Proteon Pharmaceuticals SA in Poland uses phages to treat the contamination in aquaculture and poultry farming [132-134].

The process of Good Manufacturing Practice (GMP) guidelines [135] is a gold-standard to make sure that the phage products are of high quality and efficacy and are safe to use as a medical product. In addition to various expert advices which include a minimum starting point, specifications for materials, primary containers, cleaning and decontamination, process, quality control methods, infrastructure, pharmaceutical responsibilities, quality assurance, and workers [136].

Phage biotechnology might be beneficial to countries other than EU/US due to its direct effect on the majority of human population. Australia is well positioned to perform clinical trials in phage-based technology [137]. The majority of patent documents were introduced by non-profit organizations in Asia [138]. Phages are good biocontrol agents against pathogens in foods, agriculture and aquaculture [139-141] and dairy products [142]. Phage are effective in integrated plant protection for maintainable crop production [143] and wastewater treatment [144]. Phage have been shown to target the zoonotic bacteria that colonize the intestines of farm animals [8]. Phage biotechnology has the potential to remedy a number of challenges to sustainably and phage training will be key to developing appropriate phage interventions.

\section{Conclusions}

In conclusion, phages change their behavior based on different environmental variables; for example, phages convert their mode of action from lysogenic to lytic mode and vice versa by controlling the expression of the lytic gene cluster in response to internal or external host stress. In addition, phages can communicate by secreting a peptide to assure the communal action of all phages against the environmental conditions. Moreover, the majority of phages used in biocontrol are virulent with a narrow range of target bacterial strains. Host range expansion, through natural co-evolution or genetic engineering, will be needed to enhance the efficiency of phage therapy against diseases. By training phages, they become able to adapt to bacterial resistance and phage cocktails widen the phage host range. Being able to co-evolve, the phage is of higher potential to overcome obstacles posed by the phage-resistant bacteria. Thus, further studies should try to study the co-evolution between phage and its host bacteria. Nevertheless, producing a trained phage in vitro does not reflect all the possible complications that occurs in vivo during the therapy.

Although different bacteria strains showed resistance mechanisms against the phages, as well as antibiotics, phages are developing various mechanisms to fend off the resistant bacteria. Phage resistance is achieved when bacteria block/truncate phage receptors, produce membrane-associated proteins to decoy phage receptors, activate CRISPR-Cas systems and the innate defense mechanisms (prokaryotic argonautes), activate Abi, and BREX. As a response, phages evolve diverse mechanisms to overcome the bacterial resistance via generating polysaccharide lyases/hydrolase, methylation, mutation accumulation, and Acr. Moreover, Phages could also show very promising antimicrobial agents not only as antibacterial agents but also as an antiviral and antifungal agents. This may open new era of research focus. 
Author Contributions: Conceptualization, A.S.A., N.R.; Project administration A.S.A., A.D.; writingoriginal draft preparation, A.S., A.S.A., N.R., S.M.; Writing-review \& editing A.D., P.J.R.; supervision, P.J.R. and A.E.-S.; funding acquisition, A.E.-S. All authors have read and agreed to the published version of the manuscript.

Funding: This research was funded by Academy of Scientific Research and Technology (ASRT), ASRTGenetic call (51/2020) and Zewail City of Science and Technology internal grant No. ZC 019-2019.

Institutional Review Board Statement: Not applicable.

Informed Consent Statement: Not applicable.

Data Availability Statement: Not applicable.

Acknowledgments: Many thanks to Amera Elsayed, Mariam Hebishy and Rana Nofal for their help. Figures were created with BioRender.com.

Conflicts of Interest: The authors declare no conflict of interest.

\section{References}

1. Centers for Disease Control and Prevention. Biggest Threats and Data. Antibiotic/Antimicrobial Resistance; CDC: Atlanta, GA, USA, 2019.

2. Principi, N.; Silvestri, E.; Esposito, S. Advantages and limitations of bacteriophages for the treatment of bacterial infections. Front. Pharmacol. 2019, 10. [CrossRef]

3. Navarro, F.; Muniesa, M. Phages in the human body. Front. Microbiol. 2017, 8, 566. [CrossRef] [PubMed]

4. Braga, L.P.P.; Spor, A.; Kot, W.; Breuil, M.-C.; Hansen, L.H.; Setubal, J.C.; Philippot, L. Impact of phages on soil bacterial communities and nitrogen availability under different assembly scenarios. Microbiome 2020, 8, 1-14. [CrossRef] [PubMed]

5. Ross, A.; Ward, S.; Hyman, P. More is better: Selecting for broad host range bacteriophages. Front. Microbiol. 2016, 7. [CrossRef] [PubMed]

6. Kasman, L.M.; Porter, L.D. Bacteriophages; StatPearls-NCBI Bookshelf; StatPearls Publishing: Treasure Island, FL, USA, 2019.

7. Mohamed, A.; Taha, O.; El-Sherif, H.M.; Connerton, P.L.; Hooton, S.P.T.; Bassim, N.D.; Connerton, I.F.; El-Shibiny, A. Bacteriophage ZCSE2 is a Potent Antimicrobial against Salmonella enterica Serovars: Ultrastructure, genomics and efficacy. Viruses 2020, 4, 424. [CrossRef] [PubMed]

8. Abdelsattar, A.S.; Abdelrahman, F.; Dawoud, A.; Connerton, I.F.; El-Shibiny, A. Encapsulation of E. coli phage ZCEC5 in chitosan-alginate beads as a delivery system in phage therapy. AMB Express 2019, 9, 87. [CrossRef] [PubMed]

9. Taha, O.A.; Connerton, P.L.; Connerton, I.F.; El-Shibiny, A. Bacteriophage ZCKP1: A potential treatment for Klebsiella pneumoniae isolated from diabetic foot patients. Front. Microbiol. 2018, 9, 2127. [CrossRef] [PubMed]

10. Górski, A.; Międzybrodzki, R.; Jończyk-Matysiak, E.; Żaczek, M.; Borysowski, J. Phage-specific diverse effects of bacterial viruses on the immune system. Future Microbiol. 2019. [CrossRef]

11. Zhao, G.; Vatanen, T.; Droit, L.; Park, A.; Kostic, A.D.; Poon, T.W.; Vlamakis, H.; Siljander, H.; Härkönen, T.; Hämäläinen, A.M.; et al. Intestinal virome changes precede autoimmunity in type I diabetes-susceptible children. Proc. Natl. Acad. Sci. USA 2017, 114, E6166-E6175. [CrossRef]

12. Tetz, G.; Tetz, V. Bacteriophage infections of microbiota can lead to leaky gut in an experimental rodent model. Gut Pathog. 2016, 8, 33. [CrossRef]

13. Tetz, G.V.; Ruggles, K.V.; Zhou, H.; Heguy, A.; Tsirigos, A.; Tetz, V. Bacteriophages as potential new mammalian pathogens. Sci. Rep. 2017, 7, 1-9. [CrossRef]

14. Cieplak, T.; Soffer, N.; Sulakvelidze, A.; Nielsen, D.S. A bacteriophage cocktail targeting Escherichia coli reduces E. coli in simulated gut conditions, while preserving a non-targeted representative commensal normal microbiota. Gut Microbes 2018, 9, 391-399.

15. Echeverría-Vega, A.; Morales-Vicencio, P.; Saez-Saavedra, C.; Gordillo-Fuenzalida, F.; Araya, R. A rapid and simple protocol for the isolation of bacteriophages from coastal organisms. MethodsX 2019, 6, 2614-2619. [CrossRef] [PubMed]

16. Abdelsattar, A.; Nofal, R.; Makky, S.; El-Sayed, A.; El-Shibiny, A. A Modified High-Throughput Screening Protocol to Isolate Bacteriophages from Environmental Samples. Preprints 2021. [CrossRef]

17. Azam, A.H.; Tanji, Y. Bacteriophage-host arm race: An update on the mechanism of phage resistance in bacteria and revenge of the phage with the perspective for phage therapy. Appl. Microbiol. Biotechnol. 2019, 103, 2121-2131. [CrossRef] [PubMed]

18. Abedon, S.T.; Thomas-Abedon, C. Phage therapy pharmacology. Curr. Pharm. Biotechnol. 2010, 11, 28-47. [CrossRef]

19. Abedon, S. Phage therapy pharmacology: Calculating phage dosing. In Advances in Applied Microbiology; Laskin, A., Gadd, G., Sariaslani, S., Eds.; Elsevier: Amsterdam, The Netherlands, 2011; Volume 77, pp. 1-40. ISBN 00652164.

20. Dąbrowska, K.; Miernikiewicz, P.; Piotrowicz, A.; Hodyra, K.; Owczarek, B.; Lecion, D.; Kaźmierczak, Z.; Letarov, A.; Górski, A. Immunogenicity studies of proteins forming the T4 phage head surface. J. Virol. 2014, 88, 12551-12557. [CrossRef]

21. Loc-Carrillo, C.; Abedon, S.T. Pros and cons of phage therapy. Bacteriophage 2011, 1, 111-114. [CrossRef]

22. Chen, M.; Zhang, L.; Abdelgader, S.A.; Yu, L.; Xu, J.; Yao, H.; Lu, C.; Zhang, W. Alterations in gp37 Expand the Host Range of a T4-Like Phage. Appl. Environ. Microbiol. 2017, 83, 1-12. [CrossRef] 
23. Burrowes, B.H.; Molineux, I.J.; Fralick, J.A. Directed in vitro evolution of therapeutic bacteriophages: The appelmans protocol. Viruses 2019, 11, 241. [CrossRef]

24. Laanto, E.; Mäkelä, K.; Hoikkala, V.; Ravantti, J.J.; Sundberg, L.R. Adapting a phage to combat phage resistance. Antibiotics 2020, 9, 291. [CrossRef]

25. Rohde, C.; Resch, G.; Pirnay, J.P.; Blasdel, B.G.; Debarbieux, L.; Gelman, D.; Górski, A.; Hazan, R.; Huys, I.; Kakabadze, E.; et al. Expert opinion on three phage therapy related topics: Bacterial phage resistance, phage training and prophages in bacterial production strains. Viruses 2018, 10, 178. [CrossRef] [PubMed]

26. Mapes, A.C.; Trautner, B.W.; Liao, K.S.; Ramig, R.F. Development of expanded host range phage active on biofilms of multi-drug resistant Pseudomonas aeruginosa. Bacteriophage 2016, 6, e1096995. [CrossRef] [PubMed]

27. Abdelsattar, A.S.; Nofal, R.; Makky, S.; Safwat, A.; Taha, A.; El-Shibiny, A. The Synergistic Effect of Biosynthesized Silver Nanoparticles and Phage ZCSE2 as a Novel Approach to Combat Multidrug-Resistant Salmonella enterica. Antibiotics 2021, 10, 678. [CrossRef]

28. Lopes, A.; Pereira, C.; Almeida, A. Sequential combined effect of phages and antibiotics on the inactivation of Escherichia coli. Microorganisms 2018, 6, 125. [CrossRef] [PubMed]

29. Al-Anany, A.M.; Fatima, R.; Hynes, A.P. Temperate phage-antibiotic synergy eradicates bacteria through depletion of lysogens. Cell Rep. 2021, 35, 109172. [CrossRef]

30. Huang, H.-H.; Furuta, M.; Nasu, T.; Hirono, M.; Pruet, J.; Duc, H.M.; Zhang, Y.; Masuda, Y.; Honjoh, K.; Miyamoto, T. Inhibition of phage-resistant bacterial pathogen re-growth with the combined use of bacteriophages and EDTA. Food Microbiol. 2021, 103853. [CrossRef]

31. Gutiérrez, D.; Fernández, L.; Rodríguez, A.; García, P. Practical method for isolation of phage deletion mutants. Methods Protoc. 2018, 1, 6. [CrossRef]

32. Sarhan, W.A.; Azzazy, H.M.E. Phage approved in food, why not as a therapeutic? Expert Rev. Anti. Infect. Ther. 2015, 13, 91-101. [CrossRef]

33. Voelker, R. FDA approves bacteriophage trial. JAMA 2019, 321, 638. [CrossRef]

34. Monteiro, R.; Pires, D.P.; Costa, A.R.; Azeredo, J. Phage Therapy: Going Temperate? Trends Microbiol. 2019, 27, 368-378. [CrossRef]

35. Humphrey, S.B.; Stanton, T.B.; Jensen, N.S. Mitomycin C induction of bacteriophages from Serpulina hyodysenteriae and Serpulina innocens. FEMS Microbiol. Lett. 1995, 134, 97-101. [CrossRef] [PubMed]

36. Chang, Y.; Bai, J.; Lee, J.H.; Ryu, S. Mutation of a Staphylococcus aureus temperate bacteriophage to a virulent one and evaluation of its application. Food Microbiol. 2019, 82, 523-532. [CrossRef]

37. Choi, J.; Kotay, S.M.; Goel, R. Various physico-chemical stress factors cause prophage induction in Nitrosospira multiformis 25196an ammonia oxidizing bacteria. Water Res. 2010, 44, 4550-4558. [CrossRef] [PubMed]

38. Wommack, K.E.; Colwell, R.R. Virioplankton: Viruses in Aquatic Ecosystems. Microbiol. Mol. Biol. Rev. 2000, 64, 69-114. [CrossRef] [PubMed]

39. Srinivasiah, S.; Bhavsar, J.; Thapar, K.; Liles, M.; Schoenfeld, T.; Wommack, K.E. Phages across the biosphere: Contrasts of viruses in soil and aquatic environments. Res. Microbiol. 2008, 159, 349-357. [CrossRef] [PubMed]

40. Kourilsky, P. Lysogenization by bacteriophage lambda-I. Multiple infection and the lysogenic response. MGG Mol. Gen. Genet. 1973, 122, 183-195. [CrossRef]

41. Folimonova, S.Y. Superinfection Exclusion Is an Active Virus-Controlled Function That Requires a Specific Viral Protein. J. Virol. 2012, 86, 5554-5561. [CrossRef]

42. Abedon, S.T. Bacteriophage T4 resistance to lysis-inhibition collapse. Genet. Res. 1999, 74, 1-11. [CrossRef]

43. Sblattero, D.; Bradbury, A. Exploiting recombination in single bacteria to make large phage antibody libraries. Nat. Biotechnol. 2000, 18, 75-80. [CrossRef]

44. Abedon, S.T. Commentary: Communication between Viruses Guides Lysis-Lysogeny Decisions. Front. Microbiol. 2017, 8, 983. [CrossRef]

45. Semsey, S.; Campion, C.; Mohamed, A.; Svenningsen, S. Lo How long can bacteriophage $\lambda$ change its mind? Bacteriophage 2015, 5, e1012930. [CrossRef] [PubMed]

46. Zeng, L.; Skinner, S.O.; Zong, C.; Sippy, J.; Feiss, M.; Golding, I. Decision Making at a Subcellular Level Determines the Outcome of Bacteriophage Infection. Cell 2010, 141, 682-691. [CrossRef] [PubMed]

47. Thieffry, D.; Thomas, R. Dynamical behaviour of biological regulatory networks-II. Immunity control in bacteriophage lambda. Bull. Math. Biol. 1995, 57, 277-297. [CrossRef]

48. Weitz, J.S.; Mileyko, Y.; Joh, R.I.; Voit, E.O. Collective decision making in bacterial viruses. Biophys. J. 2008, 95, 2673-2680. [CrossRef]

49. Knowles, B.; Silveira, C.B.; Bailey, B.A.; Barott, K.; Cantu, V.A.; Cobian-Guëmes, A.G.; Coutinho, F.H.; Dinsdale, E.A.; Felts, B.; Furby, K.A.; et al. Lytic to temperate switching of viral communities. Nature 2016, 531, 466-470. [CrossRef]

50. Thingstad, T.F. Elements of a theory for the mechanisms controlling abundance, diversity, and biogeochemical role of lytic bacterial viruses in aquatic systems. Limnol. Oceanogr. 2000, 45, 1320-1328. [CrossRef]

51. Maxwell, K.L. Phages Tune in to Host Cell Quorum Sensing. Cell 2019, 176, 7-8. [CrossRef]

52. Bassler, B.L.; Greenberg, E.P.; Stevens, A.M. Cross-species induction of luminescence in the quorum-sensing bacterium Vibrio harveyi. J. Bacteriol. 1997, 179, 4043-4045. [CrossRef] 
53. Bernard, C.; Li, Y.; Lopez, P.; Bapteste, E. Beyond arbitrium: Identification of a second communication system in Bacillus phage phi3T that may regulate host defense mechanisms. ISME J. 2020, 1-5. [CrossRef]

54. Erez, Z.; Steinberger-Levy, I.; Shamir, M.; Doron, S.; Stokar-Avihail, A.; Peleg, Y.; Melamed, S.; Leavitt, A.; Savidor, A.; Albeck, S.; et al. Communication between viruses guides lysis-lysogeny decisions. Nature 2017, 541, 488-493. [CrossRef] [PubMed]

55. Harms, A.; Diard, M. Crowd Controlled-Host Quorum Sensing Drives Phage Decision. Cell Host Microbe 2019, $25,179-181$. [CrossRef] [PubMed]

56. Shao, Q.; Trinh, J.T.; Zeng, L. High-resolution studies of lysis-lysogeny decision-making in bacteriophage lambda. J. Biol. Chem. 2019, 294, 3343-3349. [PubMed]

57. Domingo-Calap, P.; Mora-Quilis, L.; Sanjuán, R. Social bacteriophages. Microorganisms 2020, 8, 533. [CrossRef] [PubMed]

58. Díaz-Muñoz, S.L.; Sanjuán, R.; West, S. Sociovirology: Conflict, cooperation, and communication among viruses. Cell Host Microbe 2017, 22, 437-441. [CrossRef]

59. Koskella, B.; Brockhurst, M.A. Bacteria-phage coevolution as a driver of ecological and evolutionary processes in microbial communities. FEMS Microbiol. Rev. 2014, 38, 916-931. [CrossRef] [PubMed]

60. Labrie, S.J.; Samson, J.E.; Moineau, S. Bacteriophage resistance mechanisms. Nat. Rev. Microbiol. 2010, 8, 317-327. [CrossRef]

61. Nordström, K.; Forsgren, A. Effect of Protein A on Adsorption of Bacteriophages to Staphylococcus aureus. J. Virol. 1974. [CrossRef] [PubMed]

62. Riede, I.; Eschbach, M.L. Evidence that TraT interacts with OmpA of Escherichia coli. FEBS Lett. 1986. [CrossRef]

63. Hanlon, G.W.; Denyer, S.P.; Olliff, C.J.; Ibrahim, L.J. Reduction in Exopolysaccharide Viscosity as an Aid to Bacteriophage Penetration through Pseudomonas aeruginosa Biofilms. Appl. Environ. Microbiol. 2001. [CrossRef]

64. Sutherland, I.W. Polysaccharide lyases. FEMS Microbiol. Rev. 1995. [CrossRef]

65. Hammad, A.M.M. Evaluation of alginate-encapsulated Azotobacter chroococcum as a phage-resistant and an effective inoculum. J. Basic Microbiol. 1998. [CrossRef]

66. Destoumieux-Garzón, D.; Duquesne, S.; Peduzzi, J.; Goulard, C.; Desmadril, M.; Letellier, L.; Rebuffat, S.; Boulanger, P. The iron-siderophore transporter FhuA is the receptor for the antimicrobial peptide microcin J25: Role of the microcin Val11-Pro16 $\beta$-hairpin region in the recognition mechanism. Biochem. J. 2005, 389, 869-876. [CrossRef]

67. Seed, K.D. Battling Phages: How Bacteria Defend against Viral Attack. PLoS Pathog. 2015. [CrossRef]

68. Pingoud, A.; Jeltsch, A. Structure and function of type II restriction endonucleases. Nucleic Acids Res. 2001. [CrossRef]

69. Bickle, T.A.; Kruger, D.H. Biology of DNA restriction. Microbiol. Rev. 1993. [CrossRef]

70. Bair, C.L.; Rifat, D.; Black, L.W. Exclusion of Glucosyl-Hydroxymethylcytosine DNA Containing Bacteriophages Is Overcome by the Injected Protein Inhibitor IPI*. J. Mol. Biol. 2007, 366, 779-789. [CrossRef]

71. Rifat, D.; Wright, N.T.; Varney, K.M.; Weber, D.J.; Black, L.W. Restriction Endonuclease Inhibitor IPI* of Bacteriophage T4: A Novel Structure for a Dedicated Target. J. Mol. Biol. 2008, 375, 720-734. [CrossRef]

72. Koonin, E.V.; Makarova, K.S.; Zhang, F. Diversity, classification and evolution of CRISPR-Cas systems. Curr. Opin. Microbiol. 2017, 37, 67-78. [CrossRef]

73. Sashital, D.G.; Wiedenheft, B.; Doudna, J.A. Mechanism of Foreign DNA Selection in a Bacterial Adaptive Immune System. Mol. Cell 2012, 46, 606-615. [CrossRef]

74. Sinkunas, T.; Gasiunas, G.; Waghmare, S.P.; Dickman, M.J.; Barrangou, R.; Horvath, P.; Siksnys, V. In vitro reconstitution of Cascade-mediated CRISPR immunity in Streptococcus thermophilus. EMBO J. 2013. [CrossRef]

75. Zetsche, B.; Gootenberg, J.S.; Abudayyeh, O.O.; Slaymaker, I.M.; Makarova, K.S.; Essletzbichler, P.; Volz, S.E.; Joung, J.; Van Der Oost, J.; Regev, A.; et al. Cpf1 Is a Single RNA-Guided Endonuclease of a Class 2 CRISPR-Cas System. Cell 2015, 163, 759-771. [CrossRef] [PubMed]

76. Pyenson, N.C.; Gayvert, K.; Varble, A.; Elemento, O.; Marraffini, L.A. Broad Targeting Specificity during Bacterial Type III CRISPR-Cas Immunity Constrains Viral Escape. Cell Host Microbe 2017. [CrossRef]

77. Meeske, A.J.; Marraffini, L.A. RNA Guide Complementarity Prevents Self-Targeting in Type VI CRISPR Systems. Mol. Cell 2018, 71, 791-801.e3. [CrossRef] [PubMed]

78. Abudayyeh, O.O.; Gootenberg, J.S.; Konermann, S.; Joung, J.; Slaymaker, I.M.; Cox, D.B.T.; Shmakov, S.; Makarova, K.S.; Semenova, E.; Minakhin, L.; et al. C2c2 is a single-component programmable RNA-guided RNA-targeting CRISPR effector. Science 2016. [CrossRef] [PubMed]

79. Hegge, J.W.; Swarts, D.C.; Van Der Oost, J. Prokaryotic argonaute proteins: Novel genome-editing tools? Nat. Rev. Microbiol. 2018. [CrossRef]

80. Swarts, D.C.; Szczepaniak, M.; Sheng, G.; Chandradoss, S.D.; Zhu, Y.; Timmers, E.M.; Zhang, Y.; Zhao, H.; Lou, J.; Wang, Y.; et al. Autonomous Generation and Loading of DNA Guides by Bacterial Argonaute. Mol. Cell 2017. [CrossRef]

81. Zander, A.; Willkomm, S.; Ofer, S.; Van Wolferen, M.; Egert, L.; Buchmeier, S.; Stöckl, S.; Tinnefeld, P.; Schneider, S.; Klingl, A.; et al. Guide-independent DNA cleavage by archaeal Argonaute from Methanocaldococcus jannaschii. Nat. Microbiol. 2017, 2. [CrossRef]

82. Willkomm, S.; Oellig, C.A.; Zander, A.; Restle, T.; Keegan, R.; Grohmann, D.; Schneider, S. Structural and mechanistic insights into an archaeal DNA-guided Argonaute protein. Nat. Microbiol. 2017, 2, 1-7. [CrossRef]

83. Maxwell, K.L. The anti-CRISPR story: A battle for survival. Mol. Cell 2017, 68, 8-14. [CrossRef]

84. Fineran, P.C.; Blower, T.R.; Foulds, I.J.; Humphreys, D.P.; Lilley, K.S.; Salmond, G.P.C. The phage abortive infection system, ToxIN, functions as a protein-RNA toxin-antitoxin pair. Proc. Natl. Acad. Sci. USA 2009. [CrossRef] 
85. Song, S.; Wood, T.K. Post-segregational killing and phage inhibition are not mediated by cell death through toxin/antitoxin systems. Front. Microbiol. 2018, 9, 814. [CrossRef] [PubMed]

86. Rostøl, J.T.; Marraffini, L. (Ph)ighting Phages: How Bacteria Resist Their Parasites. Cell Host Microbe 2019. [CrossRef] [PubMed]

87. Kȩsik-Szeloch, A.; Drulis-Kawa, Z.; Weber-Dabrowska, B.; Kassner, J.; Majkowska-Skrobek, G.; Augustyniak, D.; ŁusiakSzelachowska, M.; Zaczek, M.; Górski, A.; Kropinski, A.M. Characterising the biology of novel lytic bacteriophages infecting multidrug resistant Klebsiella pneumoniae. Virol. J. 2013. [CrossRef] [PubMed]

88. Krüger, D.H.; Barcak, G.J.; Smith, H.O. Abolition of DNA recognition site resistance to the restriction endonuclease EcoRII. Biomed. Biochim. Acta 1988.

89. Ge, H.; Hu, M.; Zhao, G.; Du, Y.; Xu, N.; Chen, X.; Jiao, X. The "fighting wisdom and bravery" of tailed phage and host in the process of adsorption. Microbiol. Res. 2020, 230, 126344. [CrossRef]

90. Knecht, L.E.; Veljkovic, M.; Fieseler, L. Diversity and Function of Phage Encoded Depolymerases. Front. Microbiol. 2020. [CrossRef]

91. Pawluk, A.; Davidson, A.R.; Maxwell, K.L. Anti-CRISPR: Discovery, mechanism and function. Nat. Rev. Microbiol. 2018, 16, 12-17. [CrossRef]

92. Stanley, S.Y.; Borges, A.L.; Chen, K.H.; Swaney, D.L.; Krogan, N.J.; Bondy-Denomy, J.; Davidson, A.R. Anti-CRISPR-Associated Proteins Are Crucial Repressors of Anti-CRISPR Transcription. Cell 2019. [CrossRef] [PubMed]

93. Sun, C.L.; Barrangou, R.; Thomas, B.C.; Horvath, P.; Fremaux, C.; Banfield, J.F. Phage mutations in response to CRISPR diversification in a bacterial population. Environ. Microbiol. 2013, 15, 463-470. [CrossRef]

94. Samson, J.E.; Magadán, A.H.; Sabri, M.; Moineau, S. Revenge of the phages: Defeating bacterial defences. Nat. Rev. Microbiol. 2013. [CrossRef]

95. Blower, T.R.; Evans, T.J.; Przybilski, R.; Fineran, P.C.; Salmond, G.P.C. Viral Evasion of a Bacterial Suicide System by RNA-Based Molecular Mimicry Enables Infectious Altruism. PLoS Genet. 2012. [CrossRef]

96. Mizoguchi, K.; Morita, M.; Fischer, C.R.; Yoichi, M.; Tanji, Y.; Unno, H. Coevolution of bacteriophage PP01 and Escherichia coli O157:H7 in continuous culture. Appl. Environ. Microbiol. 2003. [CrossRef] [PubMed]

97. Yang, Y.; Shen, W.; Zhong, Q.; Chen, Q.; He, X.; Baker, J.L.; Xiong, K.; Jin, X.; Wang, J.; Hu, F.; et al. Development of a Bacteriophage Cocktail to Constrain the Emergence of Phage-Resistant Pseudomonas aeruginosa. Front. Microbiol. 2020. [CrossRef]

98. Betts, A.; Vasse, M.; Kaltz, O.; Hochberg, M.E. Back to the future: Evolving bacteriophages to increase their effectiveness against the pathogen Pseudomonas aeruginosa PAO1. Evol. Appl. 2013. [CrossRef]

99. Betts, A.; Kaltz, O.; Hochberg, M.E. Contrasted coevolutionary dynamics between a bacterial pathogen and its bacteriophages. Proc. Natl. Acad. Sci. USA 2014. [CrossRef]

100. Scanlan, P.D.; Hall, A.R.; Blackshields, G.; Friman, V.P.; Davis, M.R.; Goldberg, J.B.; Buckling, A. Coevolution with bacteriophages drives genome-wide host evolution and constrains the acquisition of abiotic-beneficial mutations. Mol. Biol. Evol. 2015. [CrossRef]

101. Scanlan, P.D.; Buckling, A.; Hall, A.R. Experimental evolution and bacterial resistance: (Co)evolutionary costs and trade-offs as opportunities in phage therapy research. Bacteriophage 2015. [CrossRef] [PubMed]

102. De Jonge, P.A.; Nobrega, F.L.; Brouns, S.J.J.; Dutilh, B.E. Molecular and Evolutionary Determinants of Bacteriophage Host Range. Trends Microbiol. 2019, 27, 51-63. [CrossRef]

103. Abdelsattar, A.S.; Dawoud, A.; Makky, S.; Nofal, R.; Aziz, R.K.; El-Shibiny, A. Bacteriophages: From isolation to application. Curr. Pharm. Biotechnol. 2021. [CrossRef] [PubMed]

104. Dowah, A.S.A.; Clokie, M.R.J. Review of the nature, diversity and structure of bacteriophage receptor binding proteins that target Gram-positive bacteria. Biophys. Rev. 2018, 10, 535-542. [CrossRef] [PubMed]

105. Monferrer, E.; Domingo-Calap, P. Virus-Host Coevolution as a Tool for Controlling Bacterial Resistance to Phage Therapy. J. Biotechnol. Biomed. 2019, 2, 96-104. [CrossRef]

106. Wandro, S.; Oliver, A.; Gallagher, T.; Weihe, C.; England, W.; Martiny, J.B.H.; Whiteson, K. Predictable molecular adaptation of coevolving Enterococcus faeciumand lytic phage EfV12-phi1. Front. Microbiol. 2019, 10, 3192. [CrossRef] [PubMed]

107. Tzipilevich, E.; Habusha, M.; Ben-Yehuda, S. Acquisition of Phage Sensitivity by Bacteria through Exchange of Phage Receptors. Cell 2017, 168, 186-199.e12. [CrossRef] [PubMed]

108. Yosef, I.; Goren, M.G.; Globus, R.; Molshanski-Mor, S.; Qimron, U. Extending the Host Range of Bacteriophage Particles for DNA Transduction. Mol. Cell 2017, 66, 721-728.e3. [CrossRef]

109. Ando, H.; Lemire, S.; Pires, D.P.; Lu, T.K. Engineering Modular Viral Scaffolds for Targeted Bacterial Population Editing. Cell Syst. 2015, 1, 187-196. [CrossRef]

110. Borin, J.M.; Avrani, S.; Barrick, J.E.; Petrie, K.L.; Meyer, J.R. Coevolutionary phage training leads to greater bacterial suppression and delays the evolution of phage resistance. bioRxiv 2020. [CrossRef]

111. Wright, A.; Hawkins, C.H.; Änggård, E.E.; Harper, D.R. A controlled clinical trial of a therapeutic bacteriophage preparation in chronic otitis due to antibiotic-resistant Pseudomonas aeruginosa; A preliminary report of efficacy. Clin. Otolaryngol. 2009, 34, 349-357. [CrossRef]

112. Górski, A.; Międzybrodzki, R.; Łobocka, M.; Głowacka-Rutkowska, A.; Bednarek, A.; Borysowski, J.; Jończyk-Matysiak, E.; Łusiak-Szelachowska, M.; Weber-Dabrowska, B.; Bagińska, N.; et al. Phage therapy: What have we learned? Viruses 2018, 10, 288. [CrossRef] 
113. Zhvania, P.; Hoyle, N.S.; Nadareishvili, L.; Nizharadze, D.; Kutateladze, M. Phage therapy in a 16-year-old boy with netherton syndrome. Front. Med. 2017, 4, 1-5. [CrossRef]

114. Kutter, E.; De Vos, D.; Gvasalia, G.; Alavidze, Z.; Gogokhia, L.; Kuhl, S.; Abedon, S. Phage Therapy in Clinical Practice: Treatment of Human Infections. Curr. Pharm. Biotechnol. 2010, 11, 69-86. [CrossRef]

115. Khawaldeh, A.; Morales, S.; Dillon, B.; Alavidze, Z.; Ginn, A.N.; Thomas, L.; Chapman, S.J.; Dublanchet, A.; Smithyman, A.; Iredell, J.R. Bacteriophage therapy for refractory Pseudomonas aeruginosa urinary tract infection. J. Med. Microbiol. 2011, 60, 1697-1700. [CrossRef] [PubMed]

116. Weber-d, B.; Mi, R. Phage Therapy in Poland-A Centennial Journey to the First Ethically Approved Treatment Facility in Europe. Front. Microbiol. 2020, 11. [CrossRef]

117. De Vos, D.; Verbeken, G.; Quintens, J.; Pirnay, J.-P. Phage Therapy in Europe: Regulatory and Intellectual Property Protection Issues. In Phage Therapy: A Practical Approach; Górski, A., Międzybrodzki, R., Borysowski, J., Eds.; Springer International Publishing: Cham, Switzerland, 2019; pp. 363-377. ISBN 9783030267360.

118. Fauconnier, A. Phage therapy regulation: From night to dawn. Viruses 2019, 11, 352. [CrossRef]

119. Jennes, S.; Merabishvili, M.; Soentjens, P.; Pang, K.W.; Rose, T.; Keersebilck, E.; Soete, O.; François, P.M.; Teodorescu, S.; Verween, G.; et al. Use of bacteriophages in the treatment of colistin-only-sensitive Pseudomonas aeruginosa septicaemia in a patient with acute kidney injury-a case report. Crit. Care 2017, 21, 2016-2018. [CrossRef]

120. Djebara, S.; Maussen, C.; De Vos, D.; Merabishvili, M.; Damanet, B.; Pang, K.W.; De Leenheer, P.; Strachinaru, I.; Soentjens, P.; Pirnay, J.P. Processing phage therapy requests in a brussels military hospital: Lessons identified. Viruses 2019, 11, 265. [CrossRef]

121. Schooley, R.T.; Biswas, B.; Gill, J.J.; Hernandez-Morales, A.; Lancaster, J.; Lessor, L.; Barr, J.J.; Reed, S.L.; Rohwer, F.; Benler, S.; et al. Development and use of personalized bacteriophage-based therapeutic cocktails to treat a patient with a disseminated resistant Acinetobacter baumannii infection. Antimicrob. Agents Chemother. 2017, 61, 1-15. [CrossRef] [PubMed]

122. Jault, P.; Leclerc, T.; Jennes, S.; Pirnay, J.P.; Que, Y.-A.; Resch, G.; Rousseau, A.F.; Ravat, F.; Carsin, H.; Le Floch, R. Efficacy and tolerability of a cocktail of bacteriophages to treat burn wounds infected by Pseudomonas aeruginosa (PhagoBurn): A randomised, controlled, double-blind phase 1/2 trial. Lancet Infect. Dis. 2019, 19, 35-45. [CrossRef]

123. Al-Ishaq, R.K.; Skariah, S.; Büsselberg, D. Bacteriophage Treatment: Critical Evaluation of Its Application on World Health Organization Priority Pathogens. Viruses 2021, 13, 51. [CrossRef]

124. Schmalstig, A.A.; Freidy, S.; Hanafin, P.O.; Braunstein, M.; Rao, G.G. Reapproaching old treatments: Considerations for PK/PD studies on phage therapy for bacterial respiratory infections. Clin. Pharmacol. Ther. 2021. [CrossRef]

125. McCallin, S.; Sacher, J.C.; Zheng, J.; Chan, B.K. Current state of compassionate phage therapy. Viruses 2019, 11, 343. [CrossRef]

126. Ruiz Ciancio, D.; Vargas, M.R.; Thiel, W.H.; Bruno, M.A.; Giangrande, P.H.; Mestre, M.B. Aptamers as diagnostic tools in cancer. Pharmaceuticals 2018, 11, 86. [CrossRef]

127. Ju, W.; Ma, H.; Zhao, T.; Liang, S.; Zhu, D.; Wang, L.; Li, J.; Zhang, Z.; Zhou, G.; Zhong, L. Stathmin guides personalized therapy in oral squamous cell carcinoma. Cancer Sci. 2020, 111, 1303. [CrossRef]

128. Kushwaha, S.S.; Multani, R.K.; Kushwaha, N.S.; Gautam, S.; Jindal, D.G.; Arora, K.S.; Avasthi, A. Saliva as a Potential Diagnostic Tool to Evaluate Relationship between Oral Microbiome and Potentially Malignant Disorders for Prevention of Malignant Transformation. Asian Pacific J. Cancer Prev. 2021, 22, 125-129. [CrossRef] [PubMed]

129. Joczyk-Matysiak, E.; Odej, N.; Kula, D.; Owczarek, B.; Orwat, F.; Midzybrodzki, R.; Neuberg, J.; Bagiska, N.; Weber-D Browska, B.; Gorski, A. Factors determining phage stability/activity: Challenges in practical phage application. Expert Rev. Anti. Infect. Ther. 2019, 17, 583-606. [CrossRef] [PubMed]

130. Pirnay, J.P.; Verbeken, G.; Ceyssens, P.J.; Huys, I.; de Vos, D.; Ameloot, C.; Fauconnier, A. The magistral phage. Viruses 2018, 10, 64. [CrossRef]

131. Vlugt, R.; Van Der Verbeek, I.M. Bacteriophages: Therapeuticals and Alternative Applications: Onderzoeksrapport Commissie Genetische Modificatie; Wageningen University \& Research: Wageningen, The Netherlands, 2008.

132. Połaska, M.; Sokołowska, B. Bacteriophages-a new hope or a huge problem in the food industry. AIMS Microbiol. 2019, 5, 324-346. [CrossRef]

133. De Melo, A.G.; Levesque, S.; Moineau, S. Phages as friends and enemies in food processing. Curr. Opin. Biotechnol. 2018, 49, 185-190. [CrossRef]

134. Moye, Z.D.; Woolston, J.; Sulakvelidze, A. Bacteriophage applications for food production and processing. Viruses 2018, 10, 205. [CrossRef]

135. EudraLex Volume 4 Good manufacturing practice (GMP) Guidelines. Eur. Comm. Public Health 2016, 4, $2014-2016$.

136. Bretaudeau, L.; Tremblais, K.; Aubrit, F.; Meichenin, M.; Arnaud, I. Good Manufacturing Practice (GMP) Compliance for Phage Therapy Medicinal Products. Front. Microbiol. 2020, 11, 1161. [CrossRef]

137. Potent, K. The future of phage clinical trials in Australia. Microbiol. Aust. 2019, 40, 16-19. [CrossRef]

138. Holtappels, D.; Lavigne, R.; Huys, I.; Wagemans, J. Protection of phage applications in crop production: A patent landscape. Viruses 2019, 11, 277. [CrossRef] [PubMed]

139. El-Shibiny, A.; El-Sahhar, S.; Adel, M. Phage applications for improving food safety and infection control in Egypt. J. Appl. Microbiol. 2017, 123, 556-567. [CrossRef]

140. El-Shibiny, A.; Dawoud, A. Bacteriophage applications for food safety. In Biocommunication of Phages; Witzany, G., Ed.; Springer International Publishing: Cham, Switzerland, 2020; pp. 463-484. ISBN 9783030458850. 
141. Kondabagil, K.; Sicheritz-Pontén, T.; Clokie, M.R.J. inPhocus: A Local Perspective on Phage-Based Biocontrol in Agriculture and Aquaculture in India. PHAGE 2020, 1, 169-173. [CrossRef]

142. García-Anaya, M.C.; Sepulveda, D.R.; Sáenz-Mendoza, A.I.; Rios-Velasco, C.; Zamudio-Flores, P.B.; Acosta-Muñiz, C.H. Phages as biocontrol agents in dairy products. Trends Food Sci. Technol. 2020, 95, 10-20. [CrossRef]

143. Holtappels, D.; Fortuna, K.; Lavigne, R.; Wagemans, J. The future of phage biocontrol in integrated plant protection for sustainable crop production. Curr. Opin. Biotechnol. 2020, 68, 60-71. [CrossRef]

144. Jassim, S.A.A.; Limoges, R.G.; El-Cheikh, H. Bacteriophage biocontrol in wastewater treatment. World J. Microbiol. Biotechnol. 2016, 32, 70. [CrossRef] 